\title{
Explaining Participation in Regional Transnational Social Movement Organizations ${ }^{1}$
}

\author{
Dawn Wiest \\ University of Notre Dame \\ dwiest@nd.edu \\ Jackie Smith \\ University of Notre Dame \\ jsmith40@nd.edu
}

Indiana USA, August 232006

World Society Focus Paper Series

A series edited by the World Society Foundation, Zurich

\section{PUBLISHED AS:}

Dawn Wiest and Jackie Smith. 2007 "Explaining Participation in Regional Transnational Social Movement Organizations” International Journal of Comparative Sociology 48:137-166. 


\begin{abstract}
Since the late 1980s, governments have focused intensely on formalizing political and economic relationships within regions. There has also been a concurrent rise in transnational, regional level organizing among social movement activists globally, suggesting the regionalization of "global civil society." However, opportunities for participation in transnational associations vary widely across countries. In this paper, we examine the influence of international (both global and regional) institutional contexts, citizen participation in international society, and national level factors on varying levels of participation in regional transnational social movement organizations (TSMOs). We use negative binomial regression to examine relationships among these factors at three time points: 1980, 1990, and 2000. We find that in the early time period, citizen network connections to international society facilitated the formation of and participation in regionally organized TSMOs. Over time, however, regional and global institutional contexts were more predictive of participation in regional TSMOs than were international network ties. Our analysis also uncovered how qualitatively different forms of regionalism translated into significantly different levels of TSMO regionalization. In Europe, where the regional institutional structure is more elaborated than elsewhere in the world, the number of regional TSMOs in which citizens participated greatly outpaced that found elsewhere. Irrespective of international, institutional factors, however, state-level features remained crucial to explaining the development of regional TSMO sectors and the variable levels of participation in them. Citizens in states with restrictions on political rights and civil liberties had significantly lower participation in these organizations in 1990 and 2000. Even so, over time, citizens in states with more ties to global and regional multilateral processes found more ways to overcome this disadvantage and strengthen their participation in regional, transnational civil society.
\end{abstract}




\section{Introduction}

In recent years especially, analysts and observers of global politics have documented the central role that transnational associations play in developing civil society relations across borders (Boli and Thomas 1999; Sikkink and Smith 2002; Wapner 1995). Moreover, there is a reciprocal relationship between intergovernmental institutions and civil society actors. Global institutions provide focal points and opportunities for transnational citizen mobilization, and citizen-led advocacy campaigns have, in turn, shaped the evolution of global institutions (Anand 1999; Chatfield 1997; Friedman, Clark, and Hochstetler 2005; Moghadam 2000; Smith Forthcoming). As citizens' groups have become more active in global arenas, analysts have sought to better understand how global variations in access to resources and organizing opportunities affect participation in what many see as a globalizing civil society. Who participates in transnational organizations? And how are these associations organized in relation to the inter-state political arena?

While we know that the population of transnational associations has grown tremendously in recent decades, we know little else about changes in the ways people have combined across national borders to promote a variety of activities. We also know very little about how changes in the global political context affect transnational associations. In this paper we explore patterns of transnational organizing among groups formed for the explicit purpose of promoting social change, groups we call transnational social movement organizations or TSMOs. Data from the Yearbook of International Organizations show that, since the mid-1980s, a larger percentage of transnational social change organizations were organized along regional lines - a pattern that mirrors developments in intergovernmental arenas (e.g. Coleman and Underhill 1998; Fawcett and Hurrell 1995; Mansfield and Reinhardt 2003; Sidaway 2002; Taylor 2003). Two different explanations might account for this organizational pattern. One interpretation is that the regionalization of transnational organizing results from the failures of prior organizing efforts to overcome major cleavages that divide the world's regions. In other words, civil society remains polarized along the lines of tension that continue to divide governments and inhibit more effective international cooperation. Another interpretation is that regionalization reflects activists' efforts to take advantage of institutional openings to maximize their influence in supra-national political arenas.

Smith's earlier analysis (2005) of the ties between regionally organized transnational social movement organizations and other non-governmental organizations found support for the latter argument, that regionalization corresponds to institutional opportunities. A significantly greater proportion of 
regional TSMOs based in the global north than in the south maintained ties either predominately or exclusively with other regional nongovernmental organizations. But, regional TSMOs based in the global south maintained significantly more cross-regional ties than their northern counterparts. This latter finding suggests that polarization between the world's regions is not driving the patterns of regional organizing we find here. If polarization was at work, we would expect activists in the global south to be more focused on regional ties, given their relative disadvantage in global settings. Instead, these groups were far more globally oriented than their northern counterparts.

In a subsequent analysis (Wiest and Smith 2006), we found further support for the argument that institutional contexts are the principal drivers of regionalization among TSMOs. Our analysis showed that regional TSMOs based in the south were more likely to maintain ties to global intergovernmental organizations (IGOs), and they were less likely to report ties only to regional IGOs than their northern counterparts (see figure 1$)^{2}$

Figure 1 about here

This evidence not only supports an institutional explanation for why transnational SMOs have been more likely to organize along regional lines, but it also shows that forces shaping the development of a more regionally organized TSMO sector differ between regions. In the north, for instance, the institutions of the European Union are highly developed, exhibiting strong sectoral differentiation as well as varied mechanisms for the participation of civil society groups. Although not nearly as developed as in Europe, regional level institution- building in the global south has accelerated in recent years, particularly during the 1990s. Regional bodies such as the African Union, ASEAN, and Mercosur are playing increasingly important roles in global, regional, and national political and economic arenas. Influenced by global democratic norms, they are also creating openings (however small) for the input of civil society in regional-level policy making. To what extent can regional institution building explain the growth of regional TSMO sectors, as well as variation across countries with regard to participation in regional TSMOs? What other factors might explain a rising tendency for TSMOs to be organized within regions?

To address these questions, we examine the relationship between government participation in regional-level institutions and citizen participation in regional TSMOs. In a recent paper, Smith and Wiest (2005) showed that government linkages to the world polity via participation in intergovernmental organizations (IGOs) and ratification of human rights treaties had a strong, significant influence on citizen participation in TSMOs. Moreover, that research showed that government participation in IGOs was 
particularly important for understanding TSMO participation among citizens in poor countries. States with weak positions in the global economic hierarchy seek to overcome their weaknesses by joining intergovernmental organizations, and by doing so, they create the 'internal conditions' that facilitate civil society participation in transnational coalitions and movement organizations. Smith and Wiest's research lends further empirical support to case studies of transnational activism that have shown that state ties to the international system play important roles in facilitating citizen participation in transnational social movement coalitions and networks (Ball 2000; Brysk 1993; Khagram 2004; Lewis 2002; Tarrow 2005).

Other research has also shown that the consolidation of international norms such as human rights over time has fueled the expansion of transnational civil society (Tsutsui 2004; Tsutsui and Wotipka 2004). Moreover, while domestic factors such as level of democracy and national wealth were the main predictors of participation in non-governmental transnational human rights organizations in the 1970s, by the 1980s, such factors were overshadowed in importance by the facilitative effect of linkages to global civil society generally (Tsutsui and Wotipka 2004). We build upon this earlier research to consider national-level characteristics that might explain why people from different countries are more or less active in regional TSMOs. In particular, we explore the relative importance of a country's internal characteristics and its embeddedness in international contexts for understanding patters of citizen participation in regional TSMOs. We also consider whether and how factors shaping regional networks have changed over time. Data from 1980, 1990 and 2000 are used to explore shifts in the patterns of regional organizing over this important period for the expansion of transnational civil society.

\section{National and International Influences on Transnational Association}

Contemporary states are embedded in an increasingly dense network of transnational relations. As they ratify new treaties, expand the agenda of the United Nations, and increase the volume of transnational interactions in economic and other sectors, they create new possibilities as well as constraints on future actions. This embeddedness of the state within a broader context of relations has important implications for how we understand other transnational processes. For instance, the rise of intergovernmental organizations to address problems that transcend geographic borders requires that citizens seeking to influence policies on many issues must also organize to engage intergovernmental political arenas. Expanding transnational relationships between governments as well as other social actors (such as transnational corporations or civil society actors) affect the demands on governments and their range of policy choices ( Meyer, Boli, Thomas, and Ramirez 1997; Sassen 1998). Violating 
international agreements can cost governments in terms of their ability to achieve foreign policy objectives, legitimacy, as well as their capacity to manage problems emerging from global interdependence (Friedman, Clark and Hochstetler 2005).

Research on social movements shows that national political contexts have important influences on whether and how people engage in politics (see, e.g., McAdam et al. 1996; Tarrow 1996). A government's tolerance of a wide range of public associations, its overall respect for civil and political rights, and the extent to which it allows political competition among diverse parties all affect the possibilities for social movement mobilization. And although these regime characteristics may be shaped by a nation's relationships to the broader global system, all transnational relationships are filtered through this domestic context (Lewis 2002; Tarrow 2001). Thus, in attempting to understand why the citizens of different nations are more or less likely to be active in regionally organized transnational social movement organizations, we must account for the character of national regimes.

National contexts also shape possibilities for transnational mobilization by defining the access citizens have to the resources needed for political action. Key resources include financing for voluntary associations and skills relevant for political organizing work. Past research shows that citizens from countries with higher levels of income and more widespread access to education, particularly at advanced levels, will be more likely than those without such resources to be involved in political organizing both within their own countries and transnationally (Smith and Wiest 2005; cf. McCarthy and Zald 1977).

Even as factors internal to states shape people's access to resources and their space for political organizing, global level processes increasingly influence these domestic contexts. For instance, the expansion of international human rights norms and the growth of mechanisms for monitoring states' compliance with these norms enhance pressures on states to democratize their practices, and it limits their range of possible responses to internal dissent (Sassen 1998). Institutional practices at the global level have led states to adopt similar practices and organizational structures, a process known as isomorphism (Giugni 2002; Meyer, Boli, Thomas, and Ramirez 1997). The growing scale and frequency of transborder exchanges facilitates the diffusion of ideas and models for action across national boundaries, further blurring the boundaries between domestic and international politics. Thus, explaining changes in the ways people engage in politics requires sensitivity to a nation's relationships to other states and supranational institutions.

International agreements addressing trans-border problems by their nature seek to enhance international transparency. In the course of doing so, they tend to extend authority to non-state actors that can help verify or disprove states' claims, thereby fostering greater openness in transnational politics. 
This expands openings for groups that have access to information and expertise relevant to the issues addressed by a given treaty regime. Thus, an expansion of environmental treaties creates new sources of leverage for local groups providing information on states' environmental performances as well as for those with scientific expertise. International human rights bodies help to legitimize and certify human rights advocacy groups. More generally, the expansion of international forums for transnational problem solving enhances the space for new forms of claims making in these areas (Tilly 2004). We expect that variation in the extent to which a country is enmeshed in multilateral processes will help explain some of the variation in levels of citizen participation in regional TSMOs.

Global multilateral processes have facilitated the expansion of regional political spaces in which non-state actors can organize transnational collective action. The interplay of state capacities within the world system and global institutional dynamics shaped the emergence of the regional system that characterizes the world order today. As newly independent states joined the United Nations in the 1960s and 70s, and as they sought to enhance their political and economic footing vis-à-vis the "Great Powers," they consolidated their interests by forming regional blocs. In this way, the early expressions of regional cooperation that blossomed within the context of the United Nations system was a reflection of and a response to global shifts in power relations associated with the end of WWII, the growing East-West conflict, and the dissolution of the colonial empires. The United Nations responded to regional strategies by granting recognition and support to such initiatives, thus encouraging states to formalize these regional relationships. For example, as the number of African states with membership in the United Nations grew, African diplomats began to turn their attention away from regional cooperation with Asia and toward formal cooperation and integration within Africa through the formation of the Organization of African Unity. Efforts such as these were supported by the United Nations Charter, which includes explicit provisions for the formation of functional regional organizations through Articles 51, 52, and 53.

The United Nations plays another direct role in consolidating regional relationships through its regional bodies. The UN Economic Commissions (UN-EC), for example, aim to directly facilitate regional cooperation in economic development and in related areas, such as environmental protection. The Commissions are essential features of the architecture of regional cooperation and play an integral role in bolstering governments' ability to adequately address important transborder issues within the region. ${ }^{3}$ For example, the United Nations Economic Commission for Africa (ECA) contributed extensively to development projects in Africa beginning in the 1960s, including the sponsorship of a regional leadership-training institute in Dakar, Senegal. Moreover, the ECA worked closely with the OAU to establish the African Development Bank. In Europe, the "Environment for Europe" program 
takes place under the auspices of the UN-ECE. This program strengthens efforts to coordinate environmental protection and sustainable development projects across the continent.

The embeddedness of regional institutions within global institutional processes becomes clear when we also consider the legal instruments of regional integration and cooperation. For example, elaborate regional human rights systems exist within Europe, the Americas, and Africa. These systems are viewed as complements to and modifications of the global system of rights (Ouguergouz 2003). Although their enforcement capacities differ dramatically, the regional systems provide the legal language with which individuals, NGOs, and social movements can challenge the practices of states. Moreover, the compatibility between regional and global rights systems facilitates the linking of domestic, regional, and global networks organized around rights regimes.

These international factors are likely to be most relevant for patterns of transnational social movement organization when a country has direct ties to regional and global institutions-including both intergovernmental organizations (IGOs) and treaties. In addition, the extent to which a country is embedded in the world polity is also indicated by non-governmental cross-border connections, including citizen links to international non-governmental organizations (INGOs) of all kinds. Given this understanding of institutional evolution, we expect the international factors we mention to have stronger effects over time. This is because structured, routine participation in the world polity, through governments' memberships in global and regional organizations and treaties, helps "socialize" states into the norms of international society (Finnemore 1996; Riemann 2002). Risse and his colleagues (1999) refer to this as the "norms spiral," whereby a state moves from denying accusations of violations and refusing to recognize international jurisdiction to making tactical and legal concessions to eventual compliance with norms (see also Clark 2003). Evidence from other studies also suggests that transnational, or world cultural processes are becoming more influential over time. For instance, longitudinal studies by Ramirez and his colleagues and by Tsutsui and Wotipka found stronger world cultural effects on the adoption of women's suffrage and on participation in international human rights NGOs, respectively, in more recent years than they found in earlier years (Ramirez, Soysal and Shanahan 1997; Tsutsui and Wotipka 2003). Thus, while effects of a country's ties to regional and global institutions are likely to be minimal in the first time period we examine, we expect them to be stronger in the latter period. Moreover, given the ways global institutions have sought to encourage regional association, we would expect to find that over time the correspondence between ties to global and regional institutions increases. 
Figure 2 about here

Despite overall increases in global-level integration, our data show that countries vary tremendously in how extensively they are involved in a variety of transnational exchanges at governmental and societal levels. In particular, important differences remain between different regions of the world. Whereas European countries have long been on a path towards more extensive regional cooperation, the rest of the world lags behind. Regionalism in North America and in the global south is not nearly as consolidated as it is in Europe. We expect this varying density of regional integration among governments to shape patterns of mobilization by TSMOs. Indeed, a comparison of the number of TSMOs organized solely within Europe and the number organized elsewhere shows that European TSMOs account for half of all regional TSMOs active in 2000 and nearly $80 \%$ of all TSMOs organized within the global north (see Figure 2).

This evidence about variation between different world regions provides strong support for our argument that supra-national institutions play central roles in shaping patterns of transnational citizen organizing. But thus far we have only looked at broad geographic categories of north and south or geographic region. We have not yet looked for differences across national-level boundaries. This study will further test the effects of regional- and global-level institutional processes on transnational associations by introducing country-level data to our analysis.

\section{Data and Methods}

Data for this study were drawn from three editions of the Yearbook of International Associations. The editions chosen were 1980/81, 1990/91, and 2000/01 to correspond with the emergent trend of regionalization within the population of TSMOs and to also reflect important shifts in the regional infrastructure of the world polity. While regional concentrations of trade and political cooperation (as well as other forms of intra-regional exchange) have been common throughout modern history, the extent to which these concentrations have been formalized into regional agreements increased since the late 1980s (Coleman and Underhill 1998; Sidaway 2002). With regard to economic agreements, for instance, of the 76 regional economic agreements existing in 1996, half originated in the 1990s (Sidaway 2002). Moreover, during this time, older organizations, such as the Association of Southeast Asian Nations (ASEAN) and the Organization of African Unity (OAU), acquired new responsibilities that had never before been formalized. 


\subsection{Dependent variable}

From each Yearbook, the research team selected international non-governmental organizations ${ }^{4}$ that were mobilized to promote explicit social or political change goals using non-violent tactics. Coders recorded evidence about the organization's goals and activities, founding, organizational structure, ties to IGOs and other INGOs, and the geographic scope of membership. The resulting dataset included TSMOs organized around such issues as human rights, peace, labor, economic justice, environmental protection, world government, and women's rights.

From these organizational data we next created a country-level dataset that included the raw counts of regionally organized TSMOs that reported having members in the country. This raw count is our dependent variable. We included countries where state leaders were eligible to participate in regional IGOs and to ratify regional treaties in 2000. Countries from the following four regions are included in our analysis: Africa, the Americas, Southeast Asia, and Europe. ${ }^{5}$ The countries included in analysis are listed in Appendix 1.

\subsection{Independent variables}

Economic resources: Our measure of economic resources available for the formation of and participation in regional TSMOs is GDP per capita in constant U.S. dollars. We collected data on this variable for each of the three time points from the World Bank's Human Development Indicators electronic data file. Because the distributions are heavily right-skewed, we converted each distribution using a $\log 10$ transformation before entering the variables into our regression models. Like all of our independent variables except treaty ratification, GDP per capita is lagged 5 years.

Political and Civil Rights: We collected data on the availability of political resources for mobilization from the Freedom House dataset of world country ratings on political rights and civil liberties. In that dataset, countries are assigned a rating for both political rights and civil liberties on two scales ranging from 1 to 7 , with 1 representing a high degree of freedom present and 7 representing a low level of freedom. We converted the two scales to make them more intuitive, with 1 representing low freedom and 7 representing high freedom. We then took the average of the two scales to create our final variable.

Ties to international civil society: This measure is the raw count of all international nongovernmental organizations (INGOs) active in each country minus the number of regional TSMOs. The 
data were collected from the Yearbook of International Organizations for the three time points. The distributions are heavily right skewed, and we transformed them using a log 10 transformation.

State participation in IGOs: These data were also collected from the three editions of the Yearbook. The Yearbook includes separate counts for regional IGO memberships, and we used these counts to construct our regional IGO variables. The variable for global IGO participation was created by subtracting the number of regional IGOs in which a country had membership from the total number of IGO memberships for a given year.

United Nations Core Multilateral Treaty Ratification: Data on multilateral treaties were collected from the United Nations report on world commitment to the rule of law in international relations.

Prepared for the September, 2005 Millennium Summit, the report lists each of the core multilateral treaties and includes the date that a state became party to each treaty. We selected all treaties that were open to ratification before the year 2000 and for each country we recorded the year of ratification. We then calculated the total number of core treaties ratified by the countries before each year of analysis.

Regional treaties: Data on regional treaty ratification were collected from the websites of the Organization of American States, the African Union, ASEAN, and the European Union. The European Union had several categories of treaty ratification, and we selected the category that included treaties open to all European countries, irrespective of EU status. As with core multilateral treaties, we selected all treaties that were open to ratification before the year 2000 and we recorded the year of ratification for each country. We then calculated the total number of regional treaties ratified by the countries before each year of analysis. ${ }^{6}$ The distributions, however, were heavily right-skewed. We thus transformed the variable using a log 10 transformation.

\subsection{Analytic method}

Because we aim to examine institutional effects on the regional TSMO sector as a whole, our method compares the population of TSMOs at each time point rather than across distinct founding-year cohorts. Thus, each time point includes TSMOs that were active prior to that year and TSMOs that were founded around that year. This method of selection helps us to control for any systematic error related to the lag time between organizational founding and inclusion in the Yearbook. By bringing all regional TSMOs into the analysis rather than a selection of groups identified in the earliest period that remained active in 2000/01, our models better capture the effects of our independent measures on the changing population of regional TSMOs. 
Our dependent variable is a right skewed, discrete count of organizational memberships. A model that relaxes the assumptions of OLS regression and includes a parameter that accounts for unmeasured variance is therefore required. We use a generalized version of the Poisson model -- negative binomial regression estimated by maximum likelihood (see, e.g. Hammond and Holly1998; Agresti 1996). Negative binomial regression allows for the excess variability (overdispersion) that characterizes event counts (King 1989). Our models take on the following negative binomial form:

$$
\mathrm{P}\left(\mathrm{y}_{\mathrm{i}} \mid \alpha, \lambda_{\mathrm{i}}\right)=\frac{\Gamma\left(\alpha+\lambda_{\mathrm{i}}\right)}{\Gamma(\alpha) \Gamma(\mathrm{yi}+1)}\left(\frac{\alpha}{\lambda_{\mathrm{i}}+\bar{\alpha}}\right)^{\alpha}\left(\frac{\lambda_{\mathrm{i}}}{\lambda_{\mathrm{i}}+\alpha}\right)^{\mathrm{y}_{\mathrm{i}}}
$$

An overdispersion parameter, $\sigma^{2}$, is included in the models. The value of the parameter represents the factor by which the variance of $\lambda_{\mathrm{i}}$ exceeds its expectation. When $\sigma^{2}$ approaches 1 , the negative binomial model is the same as Poisson. A significant overdispersion parameter translates into a rejection of the null hypothesis that $\lambda_{\mathrm{i}}=1$.

\section{Results}

Table 1 about here

Table 1 shows that the average number of regional TSMOs with membership in any of the countries increased steadily from 1980 to 2000. While in 1980 the average was 6, in 2000 it was 24 . Further, this table reveals that some countries had a very large increase in memberships, as the maximum number of TSMOs active within countries nearly doubled from 1980 to 1990 (33 to 63) and did double from 1990 to 2000 (63 to 121). Because we expect that the European context was the most conducive to the formation of regional TSMOs throughout the period under analysis, we compared European and nonEuropean countries. Among European countries, the average number of TSMO memberships more than quadrupled between 1980 and 2000, from 14 to 59. Growth among non-European countries was also rapid, but while the overall average tripled during this time period (from 4 to 12), it remained far lower than that for Europe average.

Another important difference between Europe and other regions is the change from 1980 to 2000 in the maximum number of regional TSMOs. While the maximum number of regional TSMOs active in non-European countries doubled between 1980 and 1990 (from 10 to 20), it increased by only 1 from 
1990 to 2000. The rise in the maximum number of TSMOs evident in the overall population during the 1990s was wholly accounted for by changes in the European sector. There, the maximum number of regional TSMOs doubled between 1980 and 1990, and doubled again between 1990 and 2000. So far our findings provide preliminary support for our contention that regional institutional contexts have important consequences for the development of transnational social movement sectors within them.

Table 2 about here

We now turn to our multivariate models to assess the relative importance of domestic and international factors in explaining the variation found across countries over the three time periods. The first column of table 2 shows the results for the effects of our control variables on regional TSMO memberships in 1980. Countries with higher per capita GDP and those where political rights and civil liberties were protected had significantly more regional TSMOs active within their borders. Controlling for resources and rights, European countries also had significantly higher participation in regional TSMOs. The findings here point to the importance of both domestic factors and distinct regional contexts for facilitating the development of regional TSMO sectors.

Our second model for 1980 includes the effects of citizen links to international civil society along with our control variables. As anticipated, the countries in which citizens had more ties to international NGOs of all kinds had higher memberships in regional TSMOs, irrespective of economic resources and rights. Ties to international society serve as conduits for various kinds of informational and resource exchanges that enhance opportunities to coordinate social change agendas across national boundaries. Further, in this early year, international ties were more important for explaining variation in regional TSMO memberships than both domestic economic resources and the Europe/non-Europe regional divide.

In model 3 we test the effects on regional TSMO counts of state ties to the world polity as measured by membership in trans-regional IGOs and UN treaty ratifications. We find that both of these variables had positive, statistically significant effects. Moreover, just as civil society ties to international society eradicated the independent impact of the European regional realm on variation in regional TSMO participation, so too did state ties to the world polity. That is, countries within and outside of Europe that had more ties to trans-regional IGOs or had ratified a greater number of UN treaties had a higher number of regional TSMOs active within their borders.

In model 4, we consider the effects of regional institutional contexts on regional TSMO participation. Regional IGO memberships and regional treaty ratification were significant predictors of 
regional TSMO memberships, net all other factors. Moreover, when we control for these variables, the difference between European and non-European countries becomes significant once again. That is, European countries had significantly higher memberships in regional TSMOs when state ties to the regional institutional context were held constant. We attribute this finding to variation in the strength of association between state ties to regional governance structures and TSMO participation across the countries of individual regions. The bivariate correlation between regional IGO memberships and regional TSMO participation was .64 for European countries, where regionalism was (in relative terms) already robust by 1980 , compared to .27 for non-European countries, where regionalism was weak during this time period. Thus, idiosyncratic patterns of regional civil society development in relation to qualitatively different forms of regionalism emerge when we control for the effects of state ties to the regional institutional context.

But, in our final model for 1980, the difference between European and non-European countries in regional TSMO membership is not statistically significant. Our measure of citizen ties to international society once again is statistically significant, net all other factors. In fact, a closer examination of the data showed that it was these international ties that leveled out the differences in regional TSMO participation between non-European and European countries in 1980. When we excluded INGO participation from our full model, the lower TSMO participation of citizens in non-European countries relative to European countries once again became statistically significant (this model is not shown in the table). As Appendix 2 reveals, particularly in 2000, participation in international associations of all kinds was far higher in Europe than it was elsewhere. In year 2000, on average there were 2,302 INGOs per European country compared to 617 per non-European country. Because of this dramatic difference, European citizens were also advantaged in their mobilization into regional TSMOs.

Irrespective of the Europe/non-Europe divide as well as citizen ties to international society, where states were linked up to the regional governance system through IGO membership or treaty ratification, there were more regional TSMO memberships. In general, in 1980 the regional institutional realm was a more important explanatory factor in regional TSMO variation than was the trans-regional dimension of the world polity measured by non-regionally specific IGO membership and UN treaty ratification. Further evidence for this relationship is the greater reduction in error as measured by log likelihood for model 4 with regional world polity variables than for model 3 with trans-regional world polity variables (model 3 $\mathrm{G}^{2}=17$ and model $\left.4 \mathrm{G}^{2}=44\right)$.

Referring to the statistically significant coefficients in model 4, for every additional IGO in which a state participated in 1980, there was a $2 \%$ increase in the number of regional TSMOs. Clearly, 
quantitative differences in regional TSMO participation relative to regional IGO participation were more appreciable for countries with participation in higher numbers of regional IGOs. With regard to regional treaty ratification, which is a logged variable in the model, where ratification was $10 \%$ higher than elsewhere, regional TSMO participation increased by $5 \%$. However, state ties to international society (also logged) had the strongest quantitative impact on regional TSMO counts holding all other variables constant: a 10\% increase in INGO participation corresponded with a statistically significant $13 \%$ rise in regional TSMO participation.

Table 3 about here

Next we report our results for 1990. Beginning with model 1 in table 3, we find two important differences between 1990 and 1980. Here, wealth was not a statistically significant predictor of regional TSMO participation in the model that includes our control variables only. Moreover, although not statistically significant here, we find that wealth had a negative association with our dependent variable in 1990, and that this negative relationship was retained across all 1990 models. ${ }^{7}$ One explanation is that the relationship between GDP per capita and regional TSMO participation was confounded by population size. Smaller countries tend to be richer, and smaller countries have lower participation in transnational associations of all kinds. Thus we find, for example, that while France and Italy had lower GDP per capita than Switzerland and Luxembourg, they had higher participation in both TSMOs and international NGOs in all years under analysis. Smith and Wiest's (2005) study of variation in TSMO participation showed a significant, positive relationship between the population of a country and TSMO membership, controlling for GDP per capita. Nevertheless, when we included population size in all models for 1990 (and also for 2000), the negative relationship between GDP per capita and regional TSMO participation remained. We return to the conundrum of GDP per capita in our discussion of the models for year 2000.

The second difference we find in model 1 for 1990 compared to 1980 is that the magnitude of the coefficient for Europe is much larger. On average, European countries had 63\% more regional TSMOs than non-European countries in 1980 holding wealth and political rights constant. This difference surged to $103 \%$ by 1990 . As European regionalism deepened and expanded throughout the 1980s and into the 1990s, regional civil society also grew. The number of regional TSMOs doubled in Germany, France, Belgium and Norway, where there had been a relatively high number of TSMOs active in 1980. At the same time, citizens in Portugal, Poland and Spain, where memberships were low in 1980, also became very active in regional TSMOs over this 10 year period. Thus, by 1990, we saw the expansion of 
European civil society to include citizens of countries that were less active sites during the first wave of regionalization considered here.

Turning now to models 2 and 3, we find that again, ties to international civil society were a significant predictor of regional TSMO membership in 1990, as was state participation in global IGOs and ratification of UN treaties. Of interest also in model 3 is that when we control for state ties to the global dimension of the world polity through treaty ratification, the difference between European and non-European countries with respect to regional TSMO participation is not statistically significant. We note that this pattern was also found for 1980, and it suggests that state integration into global legal regimes encourages regional transnational mobilization regardless of regional context. As we will see below, however, this pattern does not hold when we control for state ties to the regional polity.

Model 4 includes our measures of state ties to regional institutions along with our control variables for 1990. As in 1980, where states were more engaged in regional governance through IGO participation and regional treaty ratification, citizens participated in significantly more regional TSMOs. This holds for European and non-European countries alike, and across all countries with various levels of economic resources and differential political rights protections. Significant differences remained between European and non-European countries, however, suggesting that greater participation in regional governance on the part of states (measured quantitatively) did not dissolve the qualitative differences between European and non-European contexts with regard to incentives and opportunities for regional TSMO mobilization.

Our final model for 1990 shows that compared to 1980, country differences in wealth and rights mattered for differential participation in regional TSMOs. Also, while there were not significant differences in regional TSMO participation between European countries and others in 1980, the difference was statistically significant by 1990. Citizens in European countries had significantly higher participation in regional TSMOs. The coefficients in model 4 reveal that net all other factors, regional TSMO participation in European countries was, on average, double that outside of Europe $\left(e^{-.69}\right)$. Even though several non-European countries witnessed a rise in the number of active regional TSMOs (for example, participation grew from 1 to 11 in Guinea; 6 to 16 in Indonesia; and 7 to 17 in Bolivia), they could not keep pace with the tremendous growth across Europe. Again, the evidence here supports our contention that differences in the quality, strength, and extensiveness of regional institution-building in Europe compared to other regions affected the ways in which people organized across national borders.

Citizen participation in international civil society remained significant in our final model for 1990 as did state ties to regional institutions. Irrespective of region and other control variables, where citizens 
were connected to the dense networks of international society, there was significantly higher participation in regional TSMOs. The coefficient for INGO ties (.91) suggests that on average, in countries where citizens participated in $10 \%$ more INGOs than elsewhere, regional TSMO participation was also around $10 \%$ higher. The regional institutional context also predicted participation in regional TSMOs. Where governments were involved in regional IGOs and party to regional treaties in 1990, regional TSMO sectors tended to be more robust, at least with regard to the number of active organizations in the individual countries of the region. Also pointing to the relevance of regional institutional contexts, model 4 containing our regional institutional variables once again fit the data significantly better than model 3 , which included our global institutional variables (model $3 \mathrm{G}^{2}=24.4$ and model $4 \mathrm{G}^{2}=67$ ).

Table 4 about here

We now turn to our models for 2000, the final year under consideration here. Our first model reveals the great disparity between European and non-European countries. Neither wealth nor rights mattered for predicting participation in regional TSMOs in this first model. Instead, the European context explains all of the variation we see in regional TSMO participation when we do not take into account citizen participation in international civil society or state ties to global and regional institutions. The average number of regional TSMOs active per country was $492 \%$ higher in Europe than elsewhere in 2000, up from $233 \%$ in 1990 . The regression findings once again highlight the qualitatively different approach to region building in Europe compared to other regions. Unlike in the other two years, this variable retains its significance across all of our models for the year 2000.

Models 2 and 3 report similar findings to those found for the same models in 1990. There is, however, an important difference between model 3 for 1990 and that for 2000. In 1990, both state participation in trans-regional IGOs and state ratification of core UN treaties were significant, irrespective of region. In that year, the effects of these variables were such that the disparity between Europe and elsewhere in regional TSMO counts was leveled out when we compared countries with similar levels of state ties to the global dimension of the world polity. In 2000, European countries had significantly higher participation in regional TSMOs, even in countries where governments were not strongly connected to the trans-regional dimension of the world polity, such as the Ukraine and the Czech Republic. Of importance also is that the level of statistical significance for trans-regional IGO participation and UN treaty ratification increased in 2000. Further, the fit of model 3 compared to model 1 in 2000 is much improved over that model's fit in 1990 (In $1990 \mathrm{G}^{2}=24.4$ for the difference between model 3 and model 1. In 2000 
$\mathrm{G}^{2}=48$ for the difference between model 3 and model 1). Both with regard to Europe as an institutional space and to the world polity space of trans-regional IGOs and UN treaties, institutional factors became more important between 1980 and 2000 in their impact on transnational movement mobilization within regions.

Turning now to model 4, the same result obtained for 1990 holds: the regional institutional context mattered for explaining participation in regional TSMOs, irrespective of wealth, rights, and the Europe/non-Europe divide. But again, there is an important difference between 2000 and 1990. In 1990, the fit to the data of model 4 with the regional institutional variables and controls was statistically better than that of model 3, which included our global institutional variables with controls $\left(G^{2}=42.6\right.$ for the difference between model 4 and model 3 in 1990, $\mathrm{p}<=.001$ ). The same was true for 1980 as well. But in 2000, this was not the case: model 4 with regional institutional variables did not reduce error more than model 3 with global institutional variables. This finding suggests that for the population of countries under consideration here, global institutional contexts took on more significance over time in facilitating TSMO regionalization, as interactions at the regional level became increasingly nested within global institutional dynamics. ${ }^{8}$

Comparing our final model for 2000 to the final models for the other two years further reveals the important changes that took place in transnational civil society over the time period under analysis. First we return to the conundrum of GDP per capita. Our measure of economic resources is again negatively associated with regional TSMO participation, while our rights variable retains a significant, positive association. In 2000, the bivariate relationship between GDP per capita and TSMO participation was positive and relatively strong at .59. Yet, our results show that there was relatively higher participation in regional TSMOs among lower income countries in 2000 and that this was not the case in 1980. This is seen in all of the regions, although the trend was strongest in Africa because variation in TSMO participation was much higher there. For example, the low -income countries of Niger, Mali, and Burkina Faso stood out for their relatively high participation in regional TSMOs. Angola, Libya, and Swaziland, on the other hand, all of which had much higher GDP per capita in 2000 than the three countries previously listed, had much lower participation in regional TSMOs. In Asia, Cambodia and Singapore had the same number of active regional TSMOs in 2000 (4) even though Singapore's GDP per capita was many times higher. These findings suggest that joining in regional TSMOs is an important means of overcoming resource obstacles to political participation in low-income countries.

Turning to our measure of ties to international civil society in model 4 , we find that unlike previous years, this variable does not have a significant, independent effect on participation in regional 
TSMOs. We interpret this to mean that, while international NGO networks were important catalysts for the emergence of regional TSMO sectors, the importance of these diminished over time, at least with regard to the formation of and participation in regional TSMOs. As regional TSMO sectors developed and evolved, the symbolic, informational, and material resources necessary for their survival and expansion flowed more fluidly within them, thus diminishing (to some extent at least) the significance of resource flows from outside of the region. Interestingly, however, when we exclude state ties to global IGOs or state ratification of regional treaties from the model, our measure of citizen ties to international civil society once again becomes a significant predictor of regional TSMO participation. Thus, our finding regarding the decreasing significance of ties to international civil society for regional TSMO participation is being driven by the countries where ties to global and regional polities are more institutionalized.

We also find that one of our measures of state ties to the trans-regional level of the world polity core multilateral treaty ratification - retains significance in our final model for 2000. As treaty ratification increased by one treaty, participation in regional TSMOs increased by 4\%. In 1990 and in 1980, this variable was not significant when INGOs and ties to the regional institutional context were included in the models. Moreover, state ties to trans-regional IGOs approached statistical significance in 2000. As discussed above, we argue that these findings strongly suggest the nested and evolving nature of institutional contexts. Over time, regional TSMO sectors develop in relation to institutional pressures and opportunities at regional and global levels. We also note that these longitudinal findings are consistent with theories that relate institutional changes to the activities of INGOs.

The significance in this final model of our domestic measures of resources and opportunities GDP per capita and political rights protections - points to the enduring relevance of state institutional contexts. Where citizens had more rights and freedoms, they had higher participation in regional TSMOs; where economic resources were relatively low, citizens linked to regional civil society to overcome the resource deficits that limited possibilities for social change oriented collective action in their own countries. Hence, the emergence of regional TSMO sectors can best be viewed as responses to openings at the regional institutional level facilitated by citizen engagement in the resource flows and dense networks of international civil society. Over time, however, in states with more ties to regional and global institutions, citizens in countries with fewer domestic advantages in terms of state-granted rights and economic resources were more able to take advantage of transnational institutional contexts to increase their involvement in regionally organized TSMOs. ${ }^{9}$ 


\section{Conclusions}

Our findings reveal the important ways international political institutions affect the organization of transnational collective action. We found that where states participated in regional governance through IGO memberships and regional treaty ratification, citizens engaged in significantly higher numbers of regional TSMOs. Our analysis also uncovered how qualitatively different forms of regionalism translate into significantly different levels of TSMO regionalization. In Europe, where the regional institutional structure was more elaborated by 2000 than elsewhere in the world, in terms of both the diversity of interests formally represented at the regional level and the extensiveness of international law as embodied in regional treaties, the number of regional TSMOs in which citizens participated outpaced that found elsewhere. This finding corroborates our expectation that regional institutional contexts matter tremendously for the emergence and development of regional TSMO sectors. Within these sectors, participation in regional TSMOs was predicted by state participation in regional governance. Thus, as state leaders established direct links to the regional institutions through IGO participation and regional treaty ratification, the relevant political space in which citizens organized their claims-making expanded beyond national boundaries to encompass the region as a whole.

But, we also found that over time, the relevant institutional space for social movements organized at the regional level expanded beyond regional boundaries. While regional TSMO participation was constrained by levels of state participation in regional governance in the early years, by 2000, states with more UN treaty commitments were also sites of higher levels of citizen engagement in regional TSMOs. In 1980 and 1990, network ties to actors outside of the nation-state as well as state participation in regional institutions catalyzed the emergence and development of regional TSMO sectors. Over time, more coherent pressures towards institutional integration at multiple levels ensued. Thus, core multilateral treaties and state participation in global IGOs became significant for explaining variation in regional TSMOs. This finding supports a 'connective tissue' argument that TSMOs are helping link local actors with transnational political spaces. Activists are forming regional organizations to address gaps between international law embodied in the core multilateral treaties and realities at the local level. Regional institutional spaces may provide more conducive settings for reconciling discrepancies between local and global policies and practices. That ties to international civil society were not as important to predicting participation in regional TSMOs in 2000 as they were in earlier years further supports this interpretation. While network ties to actors outside individual states are important conduits of information and resource 
exchange, and are thus important catalysts for the development of regional TSMO sectors, the expansion of the intergovernmental sphere has advanced to a point where it is creating new openings and opportunities that encourage the proliferation of regional TSMOs.

In addition to the state level institutional changes induced by both coercive and non-coercive pressures towards isomorphism as posited by world polity theorists, sociologists must pay more attention to the development of regional institutional contexts. As our research shows, there was increasing convergence between global and regional political spaces between 1980 and 2000, suggesting the multiscalar nature of isomorphic pressures on nation-states. The regional institutional spaces are integral world polity structures that have distinct effects on the organization of political participation and conflict worldwide. Further, the extent to which global and regional institutional layers are mutually reinforcing or divergent and conflicting likely varies across time and region. This variability has important implications for the organization of collective life, and for the sociological study of the relationship between macrostructure and collective action.

Our research also shows that domestic institutional features remain crucial to explaining the development of regional TSMO sectors and the variable levels of participation in regional TSMOs across countries. Although economic disadvantage did not necessarily limit citizen participation in regional TSMOs, citizens in states with restrictions on political rights and civil liberties had significantly lower participation in these organizations in 1990 and 2000. Even so, over time, it appears that citizens in states with more ties to global and regional multilateral processes found more ways to overcome this disadvantage and strengthen their participation in regional civil society. Thus, it is a mistake to view domestic and international politics as a dualism (see also Marks and McAdam 1996). This research supports the contention that international contexts can increasingly help activists overcome disadvantages within national settings. States are becoming further integrated into an ever-more formalized set of organizations and practices that will continue to shape domestic politics in key ways. The definitions of state interests and agendas, the context of regional political debates, and the vulnerability of governments to various types of pressures from international actors change with time and with a state's relationship to both regional and trans-regional actors and institutions. We therefore must see states as embedded in transnational political contexts whose influence over state practice and citizen mobilization has strengthened over time. 


\section{Figure 1: Regional TSMO Ties to IGOs, Year 2000}

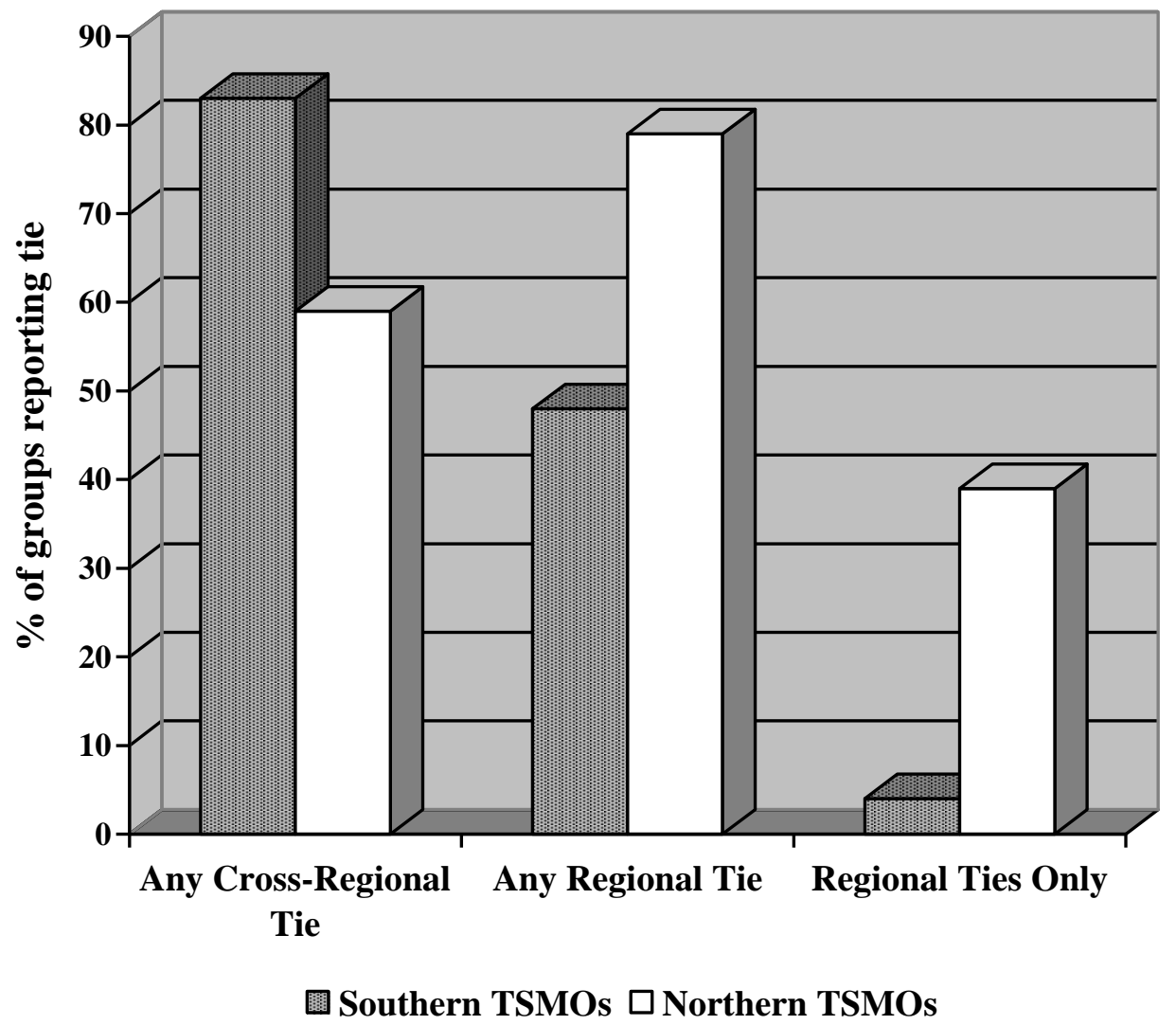

Source: Yearbook of International Organizations

Southern $\mathrm{N}=52$

Northern $\mathrm{N}=99$ 


\section{Figure 2: Northern and Southern TSMOs - Proportional Share of Population, Year 2000}

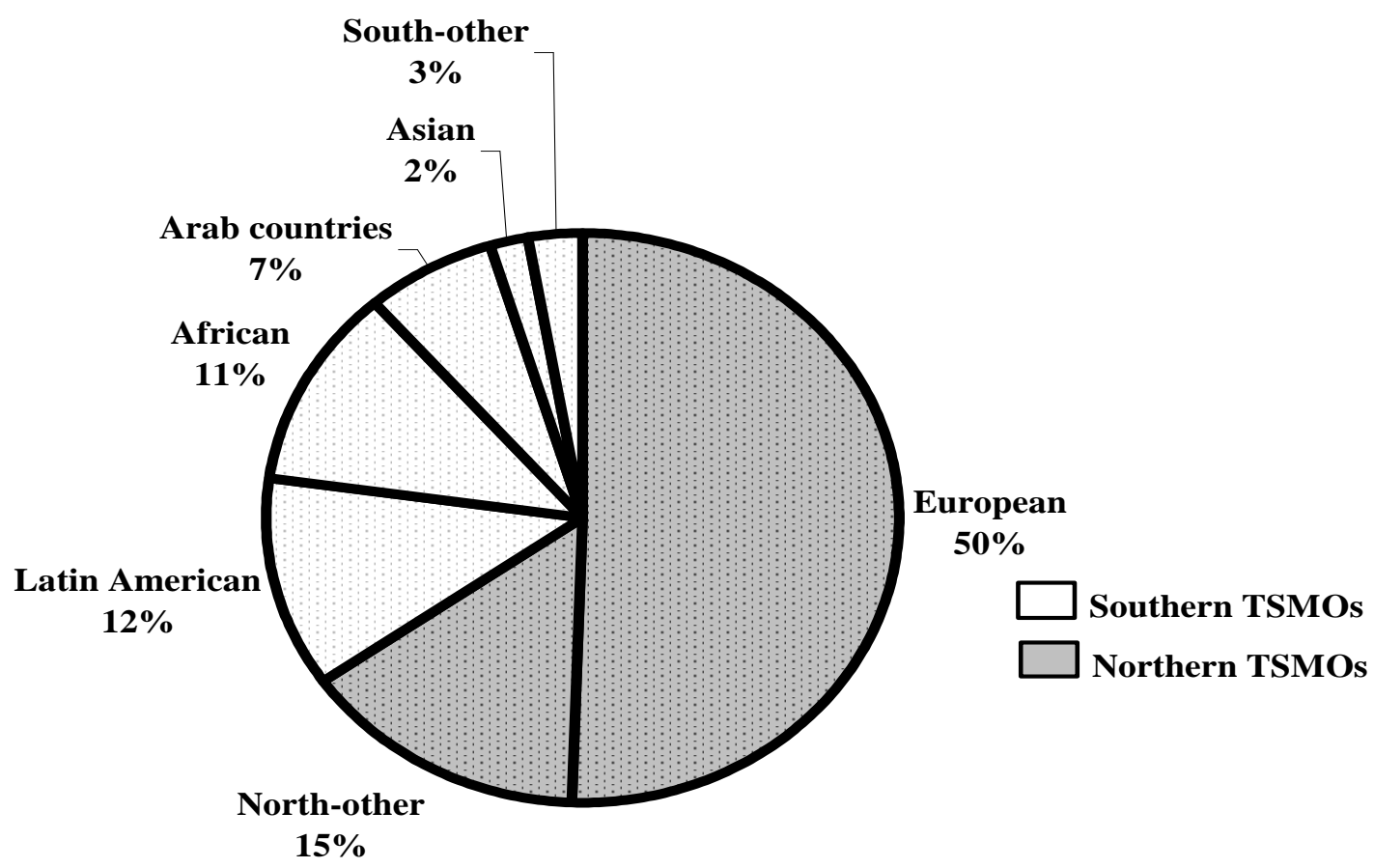

Source: Yearbook of International Organizations

Southern $\mathrm{N}=52$

Northern $\mathrm{N}=99$ 
Table 1: Regional TSMO participation

\begin{tabular}{|l|l|c|c|c|}
\hline & & $\mathbf{1 9 8 0}$ & $\mathbf{1 9 9 0}$ & $\mathbf{2 0 0 0}$ \\
\hline \multirow{3}{*}{ All countries in analysis } & & & & \\
& Mean \# orgs. & 6 & 15 & 24 \\
& Stand.dev. & 8 & 13 & 27 \\
& Range Min.-Max. & $0-33$ & $1-63$ & $2-121$ \\
\hline European countries & Mean \# orgs. & 14 & 28 & 59 \\
& Stand.dev. & 11 & 20 & 34 \\
& Range Min.-Max. & $0-33$ & $2-63$ & $14-121$ \\
\hline Countries outside of Europe & Mean \# orgs. & 4 & 9 & 12 \\
& Stand.dev. & 3 & 5 & 5 \\
& Range Min.-Max. & $0-10$ & $1-20$ & $2-21$ \\
\hline
\end{tabular}


Table 2: Results of negative binomial regression analysis of regional TSMO counts, $1980(\mathrm{~N}=113)^{1}$

\begin{tabular}{|c|c|c|c|c|c|}
\hline & 1 & 2 & 3 & 4 & 5 \\
\hline \multicolumn{6}{|l|}{ Control variables } \\
\hline GDP per capita $(\log 10)$ & $\begin{array}{l}.67 * * * \\
(.19)\end{array}$ & $\begin{array}{l}.26 \\
(.17)\end{array}$ & $\begin{array}{l}.53^{* *} \\
(.18)\end{array}$ & $\begin{array}{l}.44 * * \\
(.16)\end{array}$ & $\begin{array}{l}.18 \\
(.16)\end{array}$ \\
\hline Rights & $\begin{array}{l}.12 * * \\
(.04)\end{array}$ & $\begin{array}{l}.11 * * * \\
(.03)\end{array}$ & $\begin{array}{l}.09 * * \\
(.04)\end{array}$ & $\begin{array}{l}.04 \\
(.04)\end{array}$ & $\begin{array}{l}.05 \\
(.03)\end{array}$ \\
\hline Europe & $\begin{array}{l}.49 * \\
(.20)\end{array}$ & $\begin{array}{l}.17 \\
(.22)\end{array}$ & $\begin{array}{l}.30 \\
(.20)\end{array}$ & $\begin{array}{l}.52 * * \\
(.19)\end{array}$ & $\begin{array}{l}.32 \\
(.21)\end{array}$ \\
\hline \multicolumn{6}{|l|}{$\begin{array}{l}\text { Citizen ties to international } \\
\text { society }\end{array}$} \\
\hline $\mathrm{INGOs}^{2}(\log 10)$ & & $\begin{array}{l}1.2 * * * \\
(.19)\end{array}$ & & & $\begin{array}{l}1.2 * * * \\
(.29)\end{array}$ \\
\hline \multicolumn{6}{|l|}{$\begin{array}{l}\text { State ties to trans-regional } \\
\text { political institutions }\end{array}$} \\
\hline IGOs & & & $\begin{array}{l}.02 * \\
(.01)\end{array}$ & & $\begin{array}{l}-.02 \\
(.01)\end{array}$ \\
\hline Core UN Treaties & & & $\begin{array}{l}.09^{* *} \\
(.03)\end{array}$ & & $\begin{array}{l}.02 \\
(.03)\end{array}$ \\
\hline \multicolumn{6}{|l|}{$\begin{array}{l}\text { State ties to regional political } \\
\text { institutions }\end{array}$} \\
\hline Regional IGOs & & & & $\begin{array}{l}.03 * * * \\
(.01)\end{array}$ & $\begin{array}{l}.02 * * \\
(.01)\end{array}$ \\
\hline Regional Treaties (Log 10) & & & & $\begin{array}{l}.44 * * * \\
(.11)\end{array}$ & $\begin{array}{l}.31 * * \\
(.11)\end{array}$ \\
\hline Overdispersion parameter & $\begin{array}{l}.26 * * * \\
(.06)\end{array}$ & $\begin{array}{l}.14 * * * \\
(.06)\end{array}$ & $\begin{array}{l}.19 * * * \\
(.07)\end{array}$ & $\begin{array}{l}.11 * * * \\
(.04)\end{array}$ & $\begin{array}{l}.06 * * * \\
(.03)\end{array}$ \\
\hline Log likelihood & -282.9 & -266.5 & -274.4 & -260.7 & -251.73 \\
\hline
\end{tabular}

$* \mathrm{p}<=.05 ; * * \mathrm{p}<=.01 ; * * * \mathrm{p}<=.001$

1. Robust standard errors are in parentheses

2. For INGOs and regional treaties, a constant 1 was added before the log 10 transformation. 
Table 3: Results of negative binomial regression analysis of regional TSMO counts, $1990(\mathrm{~N}=113)^{1}$

\begin{tabular}{|c|c|c|c|c|c|}
\hline & 1 & 2 & 3 & 4 & 5 \\
\hline \multicolumn{6}{|l|}{ Control variables } \\
\hline GDP per capita $(\log 10)$ & $\begin{array}{l}-.11 \\
(.15)\end{array}$ & $\begin{array}{l}-.34 * * \\
(.13)\end{array}$ & $\begin{array}{l}-.19 \\
(.14)\end{array}$ & $\begin{array}{l}-.13 \\
(.12)\end{array}$ & $\begin{array}{l}-.28 * * \\
(.11)\end{array}$ \\
\hline Rights & $\begin{array}{l}.18 * * * \\
(.03)\end{array}$ & $\begin{array}{l}.12 * * * \\
(.03)\end{array}$ & $\begin{array}{l}.15^{* * * *} \\
(.04)\end{array}$ & $\begin{array}{l}.07 * * \\
(.03)\end{array}$ & $\begin{array}{l}.06^{*} \\
(.03)\end{array}$ \\
\hline Europe & $\begin{array}{l}.71 * * * \\
(.21)\end{array}$ & $\begin{array}{l}.40^{*} \\
(.19)\end{array}$ & $\begin{array}{l}.37 \\
(.23)\end{array}$ & $\begin{array}{l}.88^{* * * *} \\
(.19)\end{array}$ & $\begin{array}{l}.69 * * * \\
(.21)\end{array}$ \\
\hline \multicolumn{6}{|l|}{$\begin{array}{l}\text { Citizen ties to international } \\
\text { society }\end{array}$} \\
\hline $\mathrm{INGOs}^{2}(\log 10)$ & & $\begin{array}{l}1.2 * * * \\
(.16)\end{array}$ & & & $\begin{array}{l}.91 * * * \\
(.23)\end{array}$ \\
\hline \multicolumn{6}{|l|}{$\begin{array}{l}\text { State ties to trans-regional } \\
\text { political institutions }\end{array}$} \\
\hline IGOs & & & $\begin{array}{l}.03 * * \\
(.01)\end{array}$ & & $\begin{array}{l}-.01 \\
(.01)\end{array}$ \\
\hline Core UN Treaties & & & $\begin{array}{l}.05^{*} \\
(.02)\end{array}$ & & $\begin{array}{l}-.01 \\
(.02)\end{array}$ \\
\hline \multicolumn{6}{|l|}{$\begin{array}{l}\text { State ties to regional political } \\
\text { institutions }\end{array}$} \\
\hline Regional IGOs & & & & $\begin{array}{l}.01 * * * \\
(.00)\end{array}$ & $\begin{array}{l}.01 * * \\
(.00)\end{array}$ \\
\hline Regional Treaties (Log 10) & & & & $\begin{array}{l}.65^{* * *} \\
(.10)\end{array}$ & $\begin{array}{l}.52 * * * \\
(.11)\end{array}$ \\
\hline Overdispersion parameter & $\begin{array}{l}.22 * * * \\
(.21)\end{array}$ & $\begin{array}{l}.12 * * * \\
(.04)\end{array}$ & $\begin{array}{l}.16^{* * * *} \\
(.05)\end{array}$ & $\begin{array}{l}.09 * * * \\
(.03)\end{array}$ & $\begin{array}{l}.06^{* * * *} \\
(.03)\end{array}$ \\
\hline Log likelihood & -368.7 & -346.1 & -356.5 & -335.2 & -324.3 \\
\hline
\end{tabular}

$* \mathrm{p}<=.05 ; * * \mathrm{p}<=.01 ; * * * \mathrm{p}<=.001$

1. Robust standard errors are in parentheses

2. For INGOs and regional treaties, a constant 1 was added before the log 10 transformation. 
Table 4: Results of negative binomial regression analysis of regional TSMO counts, $2000(\mathrm{~N}=113)^{1}$

\begin{tabular}{|c|c|c|c|c|c|}
\hline & 1 & 2 & 3 & 4 & 5 \\
\hline \multicolumn{6}{|l|}{ Control variables } \\
\hline GDP per capita (Log 10) & $\begin{array}{l}.12 \\
(.12)\end{array}$ & $\begin{array}{l}-.22 \\
(.12)\end{array}$ & $\begin{array}{l}-.12 \\
(.10)\end{array}$ & $\begin{array}{l}-.19 \\
(.11)\end{array}$ & $\begin{array}{l}-.27 * * \\
(.11)\end{array}$ \\
\hline Rights & $\begin{array}{l}.04 \\
(.03)\end{array}$ & $\begin{array}{l}.07 * \\
(.03)\end{array}$ & $\begin{array}{l}.06^{*} \\
(.03)\end{array}$ & $\begin{array}{l}.08 * * \\
(.03)\end{array}$ & $\begin{array}{l}.08 * * \\
(.03)\end{array}$ \\
\hline Europe & $\begin{array}{l}1.4 * * * \\
(.19)\end{array}$ & $\begin{array}{l}.89 * * * \\
(.20)\end{array}$ & $\begin{array}{l}.80 * * * \\
(.19)\end{array}$ & $\begin{array}{l}1.2 * * * \\
(.15)\end{array}$ & $\begin{array}{l}.84 * * * \\
(.18)\end{array}$ \\
\hline $\begin{array}{l}\text { Citizen ties to international } \\
\text { society } \\
\qquad \operatorname{INGOs}^{2}(\log 10)\end{array}$ & & $\begin{array}{l}1.2 * * * \\
(.18)\end{array}$ & & & $\begin{array}{l}.28 \\
(.33)\end{array}$ \\
\hline \multicolumn{6}{|l|}{$\begin{array}{l}\text { State ties to trans-regional } \\
\text { political institutions }\end{array}$} \\
\hline IGOs & & & $\begin{array}{l}.04 * * * \\
(.01)\end{array}$ & & $\begin{array}{l}.02^{+} \\
(.01)\end{array}$ \\
\hline Core UN Treaties & & & $\begin{array}{l}.06 * * * \\
(.01)\end{array}$ & & $\begin{array}{l}.04 * * \\
(.01)\end{array}$ \\
\hline \multicolumn{6}{|l|}{$\begin{array}{l}\text { State ties to regional political } \\
\text { institutions }\end{array}$} \\
\hline Regional IGOs & & & & $\begin{array}{l}.03 * * * \\
(.01)\end{array}$ & $\begin{array}{l}.02 * * * \\
(.00)\end{array}$ \\
\hline Regional Treaties (Log 10) & & & & $\begin{array}{l}.66^{* * * *} \\
(.13)\end{array}$ & $\begin{array}{l}.36^{*} \\
(.17)\end{array}$ \\
\hline Overdispersion parameter & $\begin{array}{l}.19 * * * \\
(.03)\end{array}$ & $\begin{array}{l}.12 * * * \\
(.03)\end{array}$ & $\begin{array}{l}.10 * * * \\
(.02)\end{array}$ & $\begin{array}{l}.12 * * * \\
(.02)\end{array}$ & $\begin{array}{l}.08 * * * \\
(.02)\end{array}$ \\
\hline Log likelihood & -397.7 & -379.3 & -373.6 & -378.4 & -364.8 \\
\hline
\end{tabular}

$+\mathrm{p}<=.1 ; * \mathrm{p}<=.05 ; * * \mathrm{p}<=.01 ; * * * \mathrm{p}<=.001$

1. Robust standard errors are in parentheses

2. For INGOs and regional treaties, a constant 1 was added before the log 10 transformation. 
Appendix 1: Countries included in analysis

\begin{tabular}{|c|c|c|c|c|c|}
\hline \multicolumn{2}{|c|}{ Africa } & \multicolumn{2}{|c|}{ Americas } & Southeast Asia & Europe \\
\hline Algeria & Libya & Argentina & Peru & Cambodia & Albania \\
\hline Angola & Madagascar & Bahamas & St. Lucia & Indonesia & Sweden \\
\hline Benin & Malawi & Barbados & St. Vincent & Malaysia & Switzerland \\
\hline Botswana & Mali & Belize & Suriname & Philippines & Bulgaria \\
\hline Burkina Faso & Mauritania & Bolivia & Trinidad & Singapore & Cyprus $\quad$ United Kingdom \\
\hline Burundi & Mauritius & Brazil & Uruguay & Thailand & Czech Republic Ukraine \\
\hline Cameroon & Mozambique & Canada & United States & Vietnam & Denmark \\
\hline Cape Verde & Namibia & Chile & Venezuela & & Finland \\
\hline Central African Republic & Niger & Colombia & & & France \\
\hline Chad & Nigeria & Costa Rica & & & Germany \\
\hline Congo & Rwanda & Dominican Republic & & & Greece \\
\hline Congo D.R. & Senegal & Dominica & & & Hungary \\
\hline Egypt & Seychelles & Ecuador & & & Iceland \\
\hline Ethiopia & Sierra Leone & El Salvador & & & Ireland \\
\hline Gabon & South Africa & Guatemala & & & Italy \\
\hline Gambia & Sudan & Guyana & & & Luxembourg \\
\hline Ghana & Swaziland & Haiti & & & Malta \\
\hline Guinea Bissau & Tanzania & Honduras & & & Netherlands \\
\hline Guinea & Togo & Jamaica & & & Norway \\
\hline Cote d'Ivoire & Tunisia & Mexico & & & Poland \\
\hline Kenya & Uganda & Nicaragua & & & Portugal \\
\hline Lesotho & Zambia & Panama & & & Romania \\
\hline Liberia & Zimbabwe & Paraguay & & & Russia \\
\hline
\end{tabular}




\section{Appendix 2: Descriptive statistics for variables in analysis}

$\underline{\text { All countries in analysis }}$

\begin{tabular}{|c|c|c|c|c|}
\hline & & 1980 & 1990 & 2000 \\
\hline Regional TSMOs & $\begin{array}{l}\text { mean } \\
\text { s.d. } \\
\text { min } \\
\max \end{array}$ & $\begin{array}{l}6 \\
8 \\
0 \\
33\end{array}$ & $\begin{array}{l}15 \\
13 \\
1 \\
63\end{array}$ & $\begin{array}{l}24 \\
27 \\
2 \\
121\end{array}$ \\
\hline GDP per capita & $\begin{array}{l}\text { mean } \\
\text { s.d. } \\
\text { min } \\
\max \end{array}$ & $\begin{array}{l}\$ 4,110 \\
\$ 5,630 \\
\$ 123 \\
\$ 25,868\end{array}$ & $\begin{array}{l}\$ 4,820 \\
\$ 7,105 \\
\$ 93 \\
\$ 30,325\end{array}$ & $\begin{array}{l}\$ 5,713 \\
\$ 8,533 \\
\$ 49 \\
\$ 34,655\end{array}$ \\
\hline Civil and Political Rights & $\begin{array}{l}\text { mean } \\
\text { s.d. } \\
\text { min } \\
\text { max }\end{array}$ & $\begin{array}{l}4 \\
2 \\
1 \\
7\end{array}$ & $\begin{array}{l}4 \\
2 \\
1 \\
7\end{array}$ & $\begin{array}{l}5 \\
2 \\
1 \\
7\end{array}$ \\
\hline INGOs & $\begin{array}{l}\text { mean } \\
\text { s.d. } \\
\text { min } \\
\text { max }\end{array}$ & $\begin{array}{l}552 \\
547 \\
8 \\
2,161 \\
\end{array}$ & $\begin{array}{l}763 \\
719 \\
8 \\
2,777 \\
\end{array}$ & $\begin{array}{l}1,049 \\
998 \\
113 \\
3,752 \\
\end{array}$ \\
\hline Global IGOs & $\begin{array}{l}\text { mean } \\
\text { s.d. } \\
\text { min } \\
\text { max }\end{array}$ & $\begin{array}{l}30 \\
11 \\
1 \\
69\end{array}$ & $\begin{array}{l}31 \\
11 \\
11 \\
64\end{array}$ & $\begin{array}{l}34 \\
9 \\
19 \\
56\end{array}$ \\
\hline Core UN Treaties & $\begin{array}{l}\text { mean } \\
\text { s.d. } \\
\text { min } \\
\text { max }\end{array}$ & $\begin{array}{l}3 \\
2 \\
0 \\
7\end{array}$ & $\begin{array}{l}5 \\
2 \\
0 \\
9\end{array}$ & $\begin{array}{l}9 \\
3 \\
3 \\
16\end{array}$ \\
\hline Regional IGOs & $\begin{array}{l}\text { mean } \\
\text { s.d. } \\
\text { min } \\
\max \\
\end{array}$ & $\begin{array}{l}17 \\
10 \\
0 \\
51 \\
\end{array}$ & $\begin{array}{l}18 \\
10 \\
0 \\
44 \\
\end{array}$ & $\begin{array}{l}16 \\
7 \\
2 \\
39 \\
\end{array}$ \\
\hline Regional Treaties & $\begin{array}{l}\text { mean } \\
\text { s.d. } \\
\text { min } \\
\text { max }\end{array}$ & $\begin{array}{l}7 \\
7 \\
0 \\
27 \\
\end{array}$ & $\begin{array}{l}11 \\
9 \\
0 \\
33 \\
\end{array}$ & $\begin{array}{l}19 \\
12 \\
3 \\
45 \\
\end{array}$ \\
\hline
\end{tabular}




\section{Countries outside of Europe}

\begin{tabular}{|c|c|c|c|c|}
\hline & & 1980 & 1990 & 2000 \\
\hline Regional TSMOs & $\begin{array}{l}\text { mean } \\
\text { s.d. } \\
\text { min } \\
\max \end{array}$ & $\begin{array}{l}4 \\
3 \\
0 \\
10\end{array}$ & $\begin{array}{l}9 \\
5 \\
1 \\
20\end{array}$ & $\begin{array}{l}12 \\
5 \\
2 \\
21\end{array}$ \\
\hline GDP per capita & $\begin{array}{l}\text { mean } \\
\text { s.d. } \\
\text { min } \\
\text { max }\end{array}$ & $\begin{array}{l}\$ 2,144 \\
\$ 955 \\
\$ 123 \\
\$ 20,671\end{array}$ & $\begin{array}{l}\$ 2,277 \\
\$ 3,987 \\
\$ 93 \\
\$ 25,891\end{array}$ & $\begin{array}{l}\$ 2,621 \\
\$ 4,754 \\
\$ 49 \\
\$ 30,704\end{array}$ \\
\hline Civil and Political Rights & $\begin{array}{l}\text { mean } \\
\text { s.d. } \\
\text { min } \\
\max \end{array}$ & $\begin{array}{l}3 \\
2 \\
1 \\
7\end{array}$ & $\begin{array}{l}3 \\
2 \\
1 \\
7\end{array}$ & $\begin{array}{l}4 \\
2 \\
1 \\
7\end{array}$ \\
\hline INGOs & $\begin{array}{l}\text { mean } \\
\text { s.d. } \\
\text { min } \\
\max \end{array}$ & $\begin{array}{l}339 \\
290 \\
25 \\
1,528\end{array}$ & $\begin{array}{l}481 \\
378 \\
70 \\
2,051\end{array}$ & $\begin{array}{l}617 \\
518 \\
113 \\
2,858\end{array}$ \\
\hline Global IGOs & $\begin{array}{l}\text { mean } \\
\text { s.d. } \\
\text { min } \\
\max \end{array}$ & $\begin{array}{l}27 \\
9 \\
1 \\
52\end{array}$ & $\begin{array}{l}28 \\
8 \\
11 \\
64\end{array}$ & $\begin{array}{l}30 \\
7 \\
19 \\
46\end{array}$ \\
\hline Core UN Treaties & $\begin{array}{l}\text { mean } \\
\text { s.d. } \\
\text { min } \\
\text { max }\end{array}$ & $\begin{array}{l}3 \\
2 \\
0 \\
7\end{array}$ & $\begin{array}{l}5 \\
2 \\
0 \\
9\end{array}$ & $\begin{array}{l}9 \\
3 \\
3 \\
16\end{array}$ \\
\hline Regional IGOs & $\begin{array}{l}\text { mean } \\
\text { s.d. } \\
\text { min } \\
\max \end{array}$ & $\begin{array}{l}15 \\
6 \\
1 \\
28\end{array}$ & $\begin{array}{l}17 \\
9 \\
1 \\
43\end{array}$ & $\begin{array}{l}15 \\
6 \\
2 \\
30\end{array}$ \\
\hline Regional Treaties & $\begin{array}{l}\text { mean } \\
\text { s.d. } \\
\text { min } \\
\text { max }\end{array}$ & $\begin{array}{l}6 \\
7 \\
0 \\
27 \\
\end{array}$ & $\begin{array}{l}10 \\
9 \\
0 \\
33\end{array}$ & $\begin{array}{l}16 \\
13 \\
3 \\
45 \\
\end{array}$ \\
\hline
\end{tabular}


European countries

\begin{tabular}{|c|c|c|c|c|}
\hline & & 1980 & 1990 & 2000 \\
\hline Regional TSMOs & $\begin{array}{l}\text { mean } \\
\text { s.d. } \\
\text { min } \\
\max \end{array}$ & $\begin{array}{l}14 \\
11 \\
0 \\
33\end{array}$ & $\begin{array}{l}28 \\
20 \\
2 \\
63\end{array}$ & $\begin{array}{l}59 \\
34 \\
14 \\
121\end{array}$ \\
\hline GDP per capita & $\begin{array}{l}\text { mean } \\
\text { s.d. } \\
\text { min } \\
\text { max }\end{array}$ & $\begin{array}{l}9,805 \\
\$ 7,177 \\
\$ 1,063 \\
\$ 25,868\end{array}$ & $\begin{array}{l}\$ 12,189 \\
\$ 8,896 \\
\$ 1,100 \\
\$ 30,325\end{array}$ & $\begin{array}{l}\$ 14,670 \\
\$ 10,606 \\
\$ 608 \\
\$ 34,655\end{array}$ \\
\hline Civil and Political Rights & $\begin{array}{l}\text { mean } \\
\text { s.d. } \\
\text { min } \\
\text { max }\end{array}$ & $\begin{array}{l}5 \\
2 \\
1 \\
7 \\
\end{array}$ & $\begin{array}{l}5 \\
2 \\
1 \\
7 \\
\end{array}$ & $\begin{array}{l}6 \\
1 \\
4 \\
7 \\
\end{array}$ \\
\hline INGOs & $\begin{array}{l}\text { mean } \\
\text { s.d. } \\
\text { min } \\
\text { max }\end{array}$ & $\begin{array}{l}1170 \\
646 \\
8 \\
2,161 \\
\end{array}$ & $\begin{array}{l}1,581 \\
846 \\
8 \\
2,777 \\
\end{array}$ & $\begin{array}{l}2,302 \\
1,000 \\
428 \\
3,752 \\
\end{array}$ \\
\hline Global IGOs & $\begin{array}{l}\text { mean } \\
\text { s.d. } \\
\text { min } \\
\text { max }\end{array}$ & $\begin{array}{l}39 \\
12 \\
11 \\
69 \\
\end{array}$ & $\begin{array}{l}41 \\
11 \\
12 \\
53 \\
\end{array}$ & $\begin{array}{l}44 \\
7 \\
28 \\
56 \\
\end{array}$ \\
\hline Core UN Treaties & $\begin{array}{l}\text { mean } \\
\text { s.d. } \\
\text { min } \\
\text { max }\end{array}$ & $\begin{array}{l}4 \\
2 \\
0 \\
7 \\
\end{array}$ & $\begin{array}{l}6 \\
2 \\
0 \\
8 \\
\end{array}$ & $\begin{array}{l}12 \\
2 \\
5 \\
15 \\
\end{array}$ \\
\hline Regional IGOs & $\begin{array}{l}\text { mean } \\
\text { s.d. } \\
\text { min } \\
\text { max }\end{array}$ & $\begin{array}{l}24 \\
14 \\
0 \\
51 \\
\end{array}$ & $\begin{array}{l}20 \\
12 \\
0 \\
44 \\
\end{array}$ & $\begin{array}{l}20 \\
9 \\
6 \\
39 \\
\end{array}$ \\
\hline Regional Treaties & $\begin{array}{l}\text { mean } \\
\text { s.d. } \\
\text { min } \\
\text { max }\end{array}$ & $\begin{array}{l}9 \\
7 \\
0 \\
17 \\
\end{array}$ & $\begin{array}{l}14 \\
9 \\
0 \\
23 \\
\end{array}$ & $\begin{array}{l}26 \\
4 \\
14 \\
34 \\
\end{array}$ \\
\hline
\end{tabular}


Appendix 3: Zero-order correlations

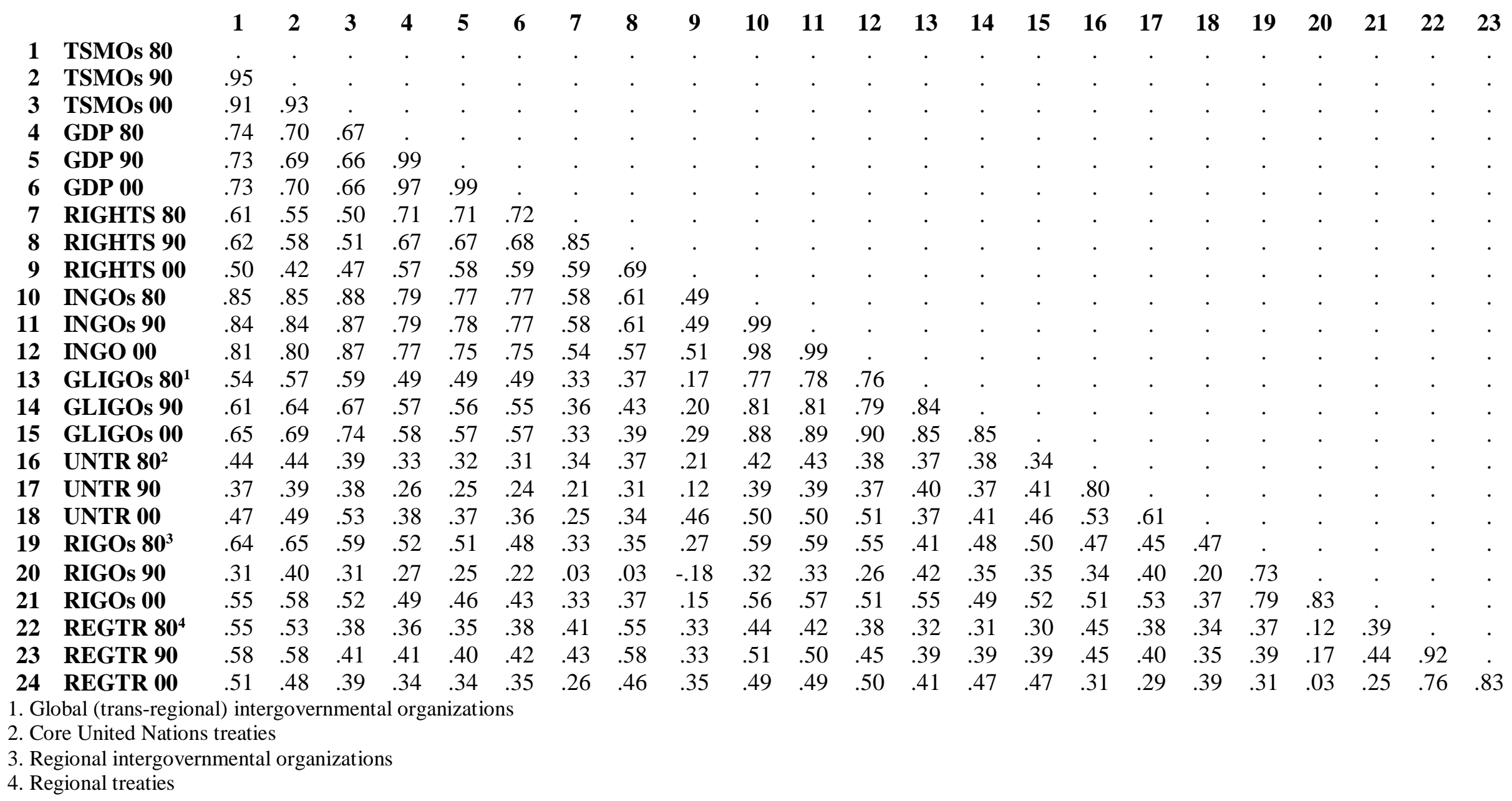




\section{References}

Anand, Anita. 1999. "Global Meeting Place: United Nations' World Conferences and Civil Society." Pp. 65-108 in Whose World is it Anyway? Civil Society, the United Nations and the Multilateral Future, edited by J. W. Foster and A. Anand. Ottawa: United Nations Association in Canada.

Ball, Patrick. 2000. "State Terror, Constitutional Traditions, and National Human Rights Movements: A Cross-National Qualitative Comparison." Pp. 54-75 in Globalizations and Social Movements: Culture, Power, and the Transnational Public Sphere, edited by J. A. Guidry, M. D. Kennedy, and M. N. Zald. Ann Arbor: University of Michigan Press.

Boli, John and George M. Thomas. 1999. "Constructing World Culture: International Nongovernmental Organizations Since 1875." Stanford: Stanford University Press.

Brysk, Alison. 1993. "From Above and Below: Social Movements, the International System, and Human Rights in Argentina." Comparative Political Studies 26: 259-285.

Chatfield, Charles. 1997. "Intergovernmental and Nongovernmental Associations to 1945." Pp. 19-41 in Transnational Social Movements and World Politics: Solidarity Beyond the State, edited by J. Smith, C. Chatfield, and R. Pagnucco. Syracuse, NY: Syracuse University Press.

Clark, Ann Marie. 2003. Diplomacy of Conscience: Amnesty International and Changing Human Rights Norms. Princeton: Princeton University Press.

Coleman, William D. and Geoffrey R.D. Underhill. 1998. "Introduction: Domestic politics, regional economic cooperation, and global economic integration." Pp. 1-19 in Regionalism and Global Economic Integration: Europe, Asia and the Americas, edited by W. D. Coleman and G. R. D. Underhill. London and New York: Routledge.

Desai, Manisha. 2002. "Multiple Mediations: The State and the Women's Movement in India." Pp. 66-85 in Social Movements: Identity, Culture, and the State, edited by D. S. Meyer, N. Whittier, and B. Robnett. Oxford and New York: Oxford University Press.

Fawcett, Louise and Andrew Hurrell. 1995. "Introduction." Pp. 1-9 in Regionalism in World Politics: Regional Organization and International Order, edited by L. Fawcett and A. Hurrell. Oxford and New York: Oxford University Press.

Finnemore, Martha. 1996. National Interests in International Society. Ithaca, NY: Cornell University Press.

Friedman, Elisabeth Jay, Ann Marie Clark, and Kathryn Hochstetler. 2005. Sovereignty, Democracy, and Global Civil Society: State-Society Relations at the UN World Conferences. New York: State University of New York Press.

Giugni, Marco G. 2002. "Explaining cross-national similarities among social movements." Pp. 13-31 in Globalization and Resistance: Transnational Dimensions of Social Movements, edited by J. Smith and H. Johnston. New York: Rowman \& Littlefield Publishers, Inc.

Khagram, Sanjeev. 2004. Dams and Development: Transnational Struggles for Water and Power. Ithaca: Cornell University Press.

Lewis, Tammy L. 2002. "Conservation TSMOs: Shaping the Protected Area Systems of Less Developed Countries." in Globalization and Resistance: Transnational Dimensions of Social Movements, edited by J. Smith and H. Johnston. New York: Rowman \& Littlefield Publishers, Inc.

Mansfield, Edward D. and Eric Reinhardt. 2003. "Multilateral Determinants of Regionalism: The effects of GATT/WTO on the Formation of Preferential Trading Arrangements." International Organization 57:829-862.

Marks, Gary and Doug McAdam. 1996. "Social Movements and the Changing Structure of Political Opportunity in the European Union." West European Politics 19:249-278.

McCarthy, John D. and Mayer Zald. 1977. "Resource Mobilization in Social Movements: A Partial Theory." American Journal of Sociology 82:1212-41.

Meyer, John. 2003. "Globalization, National Culture, and the Future of the World Polity." in Wei Lun Lecture-Chines University of Hong Kong (Nov. 2001). 
Meyer, John W., John Boli, George M. Thomas, and Francisco O. Ramirez. 1997. "World Society and the Nation-State." American Journal of Sociology 103:144-181.

Moghadam, Valentine. 2000. "Transnational Feminist Networks: Collective Action in an Era of Globalization." International Sociology 15:57-85.

Nepstad, Sharon Erickson. 2002. "Creating Transnational Solidarity: The Use of Narrative in the USCentral American Peace Movement." in Globalization and Resistance: Transnational Dimensions of Social Movements, edited by J. Smith and H. Johnston. New York: Rowman \& Littlefield Publishers, Inc.

Ouguergouz, Fatsah. 2003. The African Charter on Human and People's Rights: A Comprehensive Agenda for Human Rights Dignity and Sustainable Democracy in Africa. The Hague: Marinus Nijhoff.

Ramirez, Francisco, Yasemin Soysal, and Susanne Shanahan. 1997. "The Changing Logic of Political Citizenship: Cross-national Acquisition of Women's Suffrage." American Sociological Review 62: 735-745.

Reimann, Kim. 2002. "Building Networks from the Outside In: Japanese NGOs and the Kyoto Climate Change Conference." Pp. 173-190 in Globalization and Resistance: Transnational Dimensions of Social Movements, edited by J. Smith and H. Johnston. New York: Rowman \& Littlefield Publishers, Inc.

Risse, Thomas, Stephen C. Ropp, and Kathryn Sikkink. 1999. The Power of Human Rights: International Norms and Domestic Change. New York: Cambridge University Press.

Sassen, Saskia. 1998. Globalization and its Discontents. New York: The New Press.

Sidaway, James D. 2002. Imagined Regional Communities: Integration and Sovereignty in the Global South. New York: Routledge.

Sikkink, Kathryn and Jackie Smith. 2002. "Infrastructures for Change: Transnational Organizations, 1953-1993." Pp. 24-44 in Restructuring World Politics: The Power of Transnational Agency and Norms, edited by S. Khagram, J. Riker, and K. Sikkink. Minneapolis: University of Minnesota Press.

Smith, Jackie. 2005. "Building Bridges or Building Walls? Explaining Regionalization among Transnational Social Movement Organizations." Mobilization 10:251-270.

-. Forthcoming. Changing the World: Struggles for Global Democracy.

Smith, Jackie and Dawn Wiest. 2005. "The Uneven Geography of Global Civil Society: National and Global Influences on Transnational Association." Social Forces 84:621-651.

Tarrow, Sidney. 1996. "States and opportunities: The Political Structuring of Social Movements." Pp. 41 62 in Comparative Perspectives on Social Movements: Political Opportunities, Mobilizing Structures, and Cultural Framings, edited by D. McAdam, J. D. McCarthy, and M. N. Zald. Cambridge: Cambridge University Press.

—. 2001. "Transnational Politics: Contention and Institutions in International Politics." Annual Review of Political Science 4:1-20.

—. 2005. The New Transnational Activism: Movements, States, and International Institutions. New York: Cambridge University Press.

Taylor, Ian. 2003. "Globalization and Regionalization in Africa: Reactions to Attempts at Neo-liberal Regionalism." Review of International Political Economy 10:310-330.

Tilly, Charles. 2004. Social Movements, 1768-2004. Boulder: Paradigm Publishers.

Tsutsui, Kiyoteru. 2004. "Global Civil Society and Ethnic Social Movements in the Contemporary World." Sociological Forum 19:63-87.

Tsutsui, Kiyoteru and Christine Min Wotipka. 2004. "Global Civil Society and the International Human Rights Movement: Citizen Participation in Human Rights International Nongovernmental Organizations." Social Forces 83:587-620.

United Nations. "Multilateral Treaty Framework: An Invitation to Participate." New York: United Nations. 
Verba, Sidney, Kay Schlozman, and Henry Brady. 1995. Voice and Equality: Civic Volunteerism in American Politics. Cambridge: Harvard University Press.

Wapner, Paul. 1995. "Politics Beyond the State: Environmental Activism and World Civic Politics." World Politics 47:311-340.

Wiest, Dawn and Jackie Smith. 2006. "Regional Institutional Contexts and Patterns of Transnational Social Movement Organization." Korea Observer 37: 25-32. 


\section{End Notes}

${ }^{1}$ This research was supported by a grant from the National Science Foundation (\#SES 03-24735). Support for the early phases of the data collection work came from the American Sociological Association/NSF Funds for Advancing the Discipline Program and from the World Society Foundation.

${ }^{2}$ This same pattern of greater cross-regional ties among southern TSMOs and more regional ties among northern ones is found when we look at ties to other INGOs, although it is slightly less pronounced.

${ }^{3}$ The UNEC regions are politically rather than geographically defined, although the bulk of countries within the Economic Commission groupings are geographically proximate. For example, while the majority of countries within the UN-Economic Commission for Europe are European, Canada and the United States are also contributing members of the Commission. The other four regions represented by the Commissions are Asia and the Pacific, Latin America and the Caribbean, Africa, and Western Asia.

${ }^{4}$ In order to be included in the Yearbook, an organization must have members in at least three countries.

${ }^{5}$ APEC was not included in analysis because unlike ASEAN, it is not a treaty producing body. Moreover, like the Commonwealth, APEC is a cross-regional organization.

${ }^{6}$ We did not include treaties established through subregional bodies in Africa, the Americas, or Europe (such as ECOWAS in Africa and NAFTA and Mercosur in the Americas) because the development of non-economically oriented IGOs affiliated with these bodies, and the production of non-economic treaties has been very limited in the smaller, non-hemispheric regions outside of Southeast Asia.

${ }^{7}$ There are two major outliers in the dataset. Canada and the USA have very high GDP per capita but almost no participation in regional TSMOs. When these outliers are removed from the dataset, however, the negative association between GDP per capita and regional TSMO participation remains across models.

${ }^{8}$ The relationship between global and regional institutionalization is likely to be operating two ways: ties to global institutions encourage and reinforce regionalism at the same time as regional ties are likely to encourage links to global institutions.

${ }^{9}$ We pooled the data and tested the following interaction terms: Year $2000 *$ UN Treaties, Year $2000 *$ Global IGOs, Year 2000*Rights, and Year 2000*INGOs. The interaction terms were entered separately into NBR models that included all variables discussed above plus dummy variables for each year (Year 1980 was the omitted category). Net all other factors, the interaction of Year 2000 with UN Treaty ratification was significant ( $\mathrm{p}<=.01$ ). The coefficient for the interaction term was .06, interpreted as a $6 \%$ increase in regional TSMO counts in 2000 for every additional core UN treaty ratified. The partial coefficient for UN treaty ratification in 1980 and 1990 was not statistically significant. The Year $2000 *$ Global IGOs interaction term was also significant $(B=.02 ; \mathrm{p}<=.01)$, while the partial coefficient for the effect of IGO membership on TSMO counts in 1980 and 1990 was not. The magnitude of the coefficient for the impact on TSMO counts of political rights in 2000 was .21 ( $\mathrm{p}<=.01$ ) compared to .06 (p $<=.01$ ) for years 1980 and 1990. In the pooled dataset, the impact of INGO ties on TSMO counts for year 2000 was statistically significant $(\mathrm{B}=.26 ; \mathrm{p}<=.05)$. However, the magnitude of the partial coefficient for the effect of INGO participation on TSMO memberships for the years 1980 and 1990 was much stronger at $.82(\mathrm{p}<=.001)$. 